\title{
ANALISIS FAKTOR - FAKTOR YANG MEMPENGARUHI MINAT LULUSAN TEKNISI AKUNTANSI UNTUK BEKERJA DI BIDANG PERPAJAKAN
}

\author{
Asrofi Langgeng Noerman Syah ${ }^{1}$, Nurul Mahmudah ${ }^{2}$ \\ Email : asrofilanggeng@gmail.com \\ ${ }^{12}$ Dosen Program Studi D-III Akuntansi Politeknik Harapan Bersama Tegal
}

\begin{abstract}
Abstrak
Penelitian ini bertujuan untuk mengetahui faktor - faktor yang mempengaruhi minat lulusan teknisi akuntansi untuk bekerja dibidang perpajakan. Penelitian ini menggunakan data primer yang diperoleh dari penyebaran kuesioner. Sampel yang digunakan adalah lulusan teknisi akuntansi pada Prodi D-III Akuntansi Politeknik Harapan Bersama Tegal tahun 2017. Jumlah sampel dalam penelitian ini adalah 205 orang lulusan teknisi akuntansi. Teknik sampling yang digunakan adalah random sampling. Teknik analisa data yang digunakan adalah uji regresi linier berganda dengan menggunakan program SPSS versi 22. Hasil penelitian menunjukkan bahwa variabel pengetahuan tentang brevet pajak, sikap terhadap profesi perpajakan, norma subjektif terhadap profesi perpajakan dan kontrol perilaku terhadap profesi perpajakan berpengaruh signifikan terhadap minat lulusan teknisi akuntansi untuk bekerja dibidang perpajakan. Sedangkan variabel pengetahuan tentang pajak tidak berpengaruh terhadap minat lulusan teknisi akuntansi untuk bekerja dibidang perpajakan.
\end{abstract}

Kata Kunci : pengetahuan pajak, sikap terhadap profesi perpajakan, norma subjektif terhadap profesi perpajakan, kontrol perilaku terhadap profesi perpajakan

\section{Pendahuluan}

Indonesia merupakan negara yang terus berkembang dengan pembangunan yang dilakukan diberbagai sektor. Hal tersebut dapat dilihat dari perkembangan dunia usaha dan dunia bisnis yang semakin pesat dan dinamis sehingga membuka lapangan pekerjaan yang beragam bagi angkatan kerja. Oleh karena itu, perlu didukung dengan sumber daya manusia yang memiliki kualitas dan kompetitif serta ditunjang dengan sistem pendidikan yang sesuai dengan kebutuhan dunia kerja. Lembaga pendidikan khususnya perguruan tinggi dituntut untuk menyiapkan dan menghasilkan tenaga kerja yang berkualitas dan kompeten agar mampu bersaing didunia kerja sehingga mereka mendapatkan peluang kerja yang lebih baik. Perguruan tinggi juga harus menyiapkan lulusannya agar nantinya dapat memilih pekerjaan yang sesuai dengan kompetensi dan keahlian yang dimilikinya.

Program Studi D-III Akuntansi merupakan salah satu program studi yang paling diminati oleh mahasiswa dan akan melahirkan lulusan teknisi akuntansi. Hal ini karena instansi swasta maupun pemerintah membutuhkan tenaga teknisi akuntansi untuk mengurus masalah keuangan, yang nantinya akan menjadi dasar untuk pengambilan keputusan bagi manajemen. Selain itu terdapat beberapa faktor yang mendorong mahasiswa untuk memilih Program Studi D-III Akuntansi seperti adanya peluang kerja yang lebih banyak setelah lulus karena materi kuliah lebih aplikatif (praktek) sehingga mereka lebih siap kerja dan keinginan untuk bekerja menjadi profesional di bidang akuntansi. Oleh karena itu, setelah lulus dari perguruan tinggi diharapkan lulusan D-III Akuntansi dapat mempertimbangkan pekerjaan yang akan dipilih dengan baik sehingga nantinya dapat bekerja secara profesional dan menjadi tenaga akuntansi yang berkualitas dan kompeten.

Pekerjaan yang diinginkan oleh lulusan Teknisi Akuntansi adalah bekerja sebagai tenaga akuntansi di instansi pemerintah, swasta atau BUMN, tenaga akuntan atau staff auditor pada Kantor Akuntan Publik (KAP) dan analis kredit pada perbankan dan lembaga keuangan non-bank. Akan tetapi, beberapa tahun belakangan ini terdapat pekerjaan yang menarik bagi lulusan Teknisi Akuntansi yaitu pekerjaan di bidang perpajakan seperti 
sebagai pegawai Direktorat Jenderal Pajak, tenaga atau konsultan pajak serta tax specialist pada perusahaan. Ketiga pekerjaan tersebut memiliki perbedaan yaitu dimana pekerjaan seorang pegawai Dirjen pajak menjalankan pekerjaannya dengan motif utama sebagai pengaman penerimaan pajak bagi Negara. Pekerjaan sebagai tenaga/konsultan pajak berperan sebagai penasehat perpajakan dan menerima kuasa untuk melaksanakan kewajiban perpajakan atas nama Wajib Pajak dengan motif imbalan atau fee. Sedangkan pekerjaan sebagai Tax Specialist dapat bekerja sebagai pengelola pajak perusahaan, pengamat perpajakan ,atau pengajar (Dayshandi, Handayani, Yaningwati, 2015) $)^{[1]}$

Pekerjaan di bidang perpajakan memiliki peluang yang cukup besar bagi lulusan Teknisi Akuntansi karena pekerjaan ini masih sangat dibutuhkan serta masih kurang diminati oleh kebanyakan lulusan. Saat ini jumlah pegawai dirjen pajak berdasarkan data Biro SDM Kementerian Keuangan per 1 september 2017 adalah 39.491 orang (www.sdm.kemenkeu.go.id) ${ }^{[5]}$. Hal ini sangat tidak sebanding dengan jumlah wajib pajak yang terdaftar berdasarkan data per bulan April 2017 berjumlah 36.031.972 Wajib Pajak, dengan 16.599.632 diantaranya wajib menyampaikan SPT Tahun 2016. Selain itu, jumlah konsultan pajak yang terdaftar pada Direktorat Jendral Pajak berdasarkan sistem informasi konsultan pajak adalah 3.384 orang (www.konsultan.pajak.go.id) ${ }^{[6]}$. Perusahaan juga banyak yang mencari lulusan untuk mengembangkan dan memajukan perusahaan di bidang perpajakan.

Perusahaan merupakan wajib pajak sehingga sektor perpajakan menjadi bagian penting bagi perusahaan yang telah terdaftar sebagi wajib pajak. Perusahaan secara otomatis memiliki kewajiban untuk membayar pajak sehingga dibutuhkan lulusan yang mengerti tentang peraturan perpajakan, ketentuan umum perpajakan dan kemampuan mengolah pajak agar perusahaan dapat terhindar dari sanksi perpajakan dan kerugian pajak. Hal ini menunjukan bahwa pekerjaan dibidang perpajakan sangat dibutuhkan agar mekanisme perpajakan di Indonesia dapat berjalan dengan baik.

Lulusan Teknisi Akuntansi yang memiliki pengetahuan dan kemampuan serta lowongan pekerjaan dibidang perpajakan dapat menjadi peluang besar untuk mendapatkan pekerjaan dibidang perpajakan. Oleh karena itu, banyak perguruan tinggi yang membekali mahasiswa akuntansi dengan ilmu perpajakan. Hal ini karena adanya persepsi bahwa mahasiswa akuntansi memiliki bekal ilmu dibidang akuntansi dan dengan tambahan ilmu perpajakan maka tenaga yang berasal dari lulusan akuntansi akan lebih berpotensi dibandingkan dengan jurusan lainnya. Perusahaan juga akan cenderung lebih memilih lulusan dengan ilmu sekaligus daripada merekrut dua karyawan yang berbeda jurusan. Karyawan yang direkrut dapat membuat laporan keuangan dan dapat menghitung pajak perusahaan sekaligus sehingga dapat menghemat biaya gaji dan proses pekerjaan akan jauh lebih cepat.

Sebagai calon lulusan teknisi akuntansi maka mahasiswa seharusnya sudah memikirkan dan menyiapkan pekerjaan nantinya yang akan dipilih agar mahasiswa tidak salah dalam memilih pekerjaan. Akan tetapi, minat lulusan teknisi akuntansi untuk bekerja ternyata dipengaruhi berbagi hal seperti adanya pengetahuan tentang pajak dan brevet pajak yang dimiliki lulusan atau adanya sikap terhadap pekerjaan tersebut. Norma subjektif dan kontrol perilaku lulusan terkait dengan profesi pajak juga akan mempengaruhi keputusan kelulusan didalam memilih pekerjaan tersebut. Faktor - faktor yang mempengaruhi minat lulusan teknisi akuntansi memilih pekerjaan dibidang perpajakan merupakan hal yang menarik untuk diteliti karena dengan mengetahui pilihan pekerjaan yang diminati lulusan, maka dapat diketahui mengapa seseorang memilih pekerjaan tersebut.

Berdasarkan uraian diatas maka peneliti tertarik untuk melakukan penelitian terkait minat lulusan teknisi akuntansi untuk bekerja dibidang perpajakan sehingga dapat 
dirumuskan sebuah permasalahan dalam penelitian ini adalah faktor - faktor apa saja yang mempengaruhi minat lulusan teknisi akuntansi untuk bekerja dibidang perpajakan.

Tujuan penelitian ini adalah untuk memberikan bukti empiris mengenai berbagai faktor yang mempengaruhi minat lulusan teknisi akuntansi untuk bekerja dibidang perpajakan. Dari hasil penelitian ini dapat digunakan sebagai bahan pertimbangan dan masukan bagi Prodi D-III Akuntansi Politeknik Harapan Bersama Tegal dalam meningkatkan kualitas dan kompetensi mahasiswa D-III Akuntansi terkait ilmu perpajakan dengan kurikulum dan sertifikasi yang mendukung. Selain itu juga dapat dijadikan masukan bagi mahasiswa D-III Akuntansi untuk meningkatkan pengetahuan perpajakan sehingga dapat menjadi bekal untuk bekerja dibidang perpajakan.

\section{Metode Penelitian}

Desain penelitian ini adalah penelitian kuantitatif, dimana penelitian ini memiliki satu variabel dependen dan lima variabel independen. Variabel dependen yang digunakan dalam penelitian ini adalah minat lulusan teknisi akuntansi untuk bekerja dibidang perpajakan. Sedangkan variabel independen dalam penelitian ini adalah pengetahuan tentang pajak, pengetahuan tentang brevet pajak, sikap terhadap profesi perpajakan, norma subjektif tentang profesi perpajakan dan kontrol perilaku tentang profesi perpajakan. Jenis data yang digunakan adalah data kuantitatif dan sumber data yang digunakan adalah data primer dalam bentuk persepsi responden (subjek) penelitian. Pengambilan data menggunakan survey langsung dan instrumen yang di gunakan adalah kuesioner (angket). Kuesioner yang digunakan disusun sendiri oleh peneliti berdasarkan teori yang terkait.

Populasi dalam penelitian ini adalah lulusan Prodi D-III Akuntansi Politeknik Harapan Bersama Tegal Tahun 2017 yang berjumlah 420 orang. Sampel dalam penelitian ini diambil dengan menggunakan rumus slovin. Dengan populasi $(\mathrm{N})$ sebesar 420 lulusan teknisi akuntansi dan tingkat kesalahan (e) sebesar 5\%, maka besarnya sampel adalah:

$$
\begin{aligned}
\mathrm{n} & =\frac{N}{1+N(e)^{2}} \\
& =\frac{420}{1+420(0,05)^{2}} \\
& =\frac{420}{2,05} \\
& =204,8=205 \text { sampel }
\end{aligned}
$$

Teknik pengambilan sampling yang digunakan dalam penelitian ini adalah random sampling, yaitu teknik sampling yang anggota sampelnya dipilih secara acak sejumlah 205 sampel. Instrumen penelitian ini diukur menggunakan model Skala Likert 5 poin. Instrumen yang digunakan untuk mengukur semua variabel berjumlah 29 pertanyaan. Sebelum di analisis maka kuesioner terlebih dahulu dilakukan uji validitas dan uji reabilitas agar kuesioner tersebut dikatakan valid.

Metode analisis data yang digunakan dalam penelitian ini adalah analisis regresi linier berganda yang menggunakan program SPSS versi 22. Persamaan regresi linier berganda digambarkan dalam bentuk sebagai berikut :

$$
\mathrm{Y}=\mathrm{a}+\mathrm{B}_{1} \mathrm{X}_{1}+\mathrm{B}_{2} \mathrm{X}_{2}+\mathrm{B}_{3} \mathrm{X}_{3}+\mathrm{B}_{4} \mathrm{X}_{4}+\mathrm{B}_{5} \mathrm{X}_{5}+
$$

Keterangan :

$\mathrm{Y}=$ Minat lulusan teknisi akuntansi

$\mathrm{a}=$ konstanta

$\mathrm{X}_{1}=$ pengetahuan tentang pajak

$\mathrm{X}_{2}=$ pengetahuan brevet pajak

$\mathrm{X}_{3}=$ sikap terhadap profesi pajak

$\mathrm{X}_{4}=$ Norma subjektif profesi pajak

$\mathrm{X}_{5}=$ Kontrol perilaku profesi pajak

$\mathrm{B}_{1}=$ koefisien regresi $\mathrm{X}_{1}$

$\mathrm{B}_{2}=$ koefisien regresi $\mathrm{X}_{2}$

$\mathrm{B}_{3}=$ koefisien regresi $\mathrm{X}_{3}$

$\mathrm{B}_{4}=$ koefisien regresi $\mathrm{X}_{4}$

$\mathrm{B}_{5}=$ koefisien regresi $\mathrm{X}_{5}$

$\mathrm{e} \quad=$ kesalahan estimasi 


\section{Hasil Penelitian Dan Pembahasan}

Deskriptif Data Penelitian

Data yang diperoleh adalah kuesioner yang telah diisi oleh lulusan teknisi akuntansi Politeknik Harapan Bersama Tegal. Kuesioner disebarkan secara langsung kepada sampel penelitian. Kuesioner yang disebarkan tidak semuanya dapat digunakan dalam penelitian.

Tabel 1 Distribusi Kuesioner Penelitian

\begin{tabular}{|l|c|}
\hline \multicolumn{1}{|c|}{ Keterangan } & Jumlah Kuesioner \\
\hline $\begin{array}{l}\text { Jumlah kuesioner yang } \\
\text { disebar }\end{array}$ & 210 \\
\hline $\begin{array}{l}\text { Kuesioner yang } \\
\text { kembali akhir yang }\end{array}$ & 205 \\
\hline $\begin{array}{l}\text { Sampel and } \\
\text { digunakan }\end{array}$ & 205 \\
\hline
\end{tabular}

Sumber : Data primer diolah (2017)

\section{Uji Statistik Deskriptif}

Hasil uji statistik deskriptif data dalam penelitian ini dapat dilihat pada tabel 2 berikut ini

Tabel 2 Hasil Statistik Deskriptif

\begin{tabular}{|c|l|l|l|c|}
\hline Variabel & Min & Max & Mean & SD \\
\hline $\begin{array}{c}\text { Pengetahuan } \\
\text { pajak }\end{array}$ & 7 & 25 & 20,39 & 2,276 \\
\hline $\begin{array}{c}\text { Pengetahuan } \\
\text { brevet pajak }\end{array}$ & 10 & 25 & 19,97 & 2,493 \\
\hline $\begin{array}{c}\text { Sikap profesi } \\
\text { perpajakan }\end{array}$ & 4 & 20 & 15,96 & 2,186 \\
\hline $\begin{array}{c}\text { Norma } \\
\text { subjektif } \\
\text { profesi } \\
\text { perpajakan }\end{array}$ & 5 & 20 & 14,97 & 2,111 \\
\hline $\begin{array}{c}\text { Kontrol } \\
\text { perilaku } \\
\text { profesi } \\
\text { perpajakan }\end{array}$ & 5 & 20 & 15,09 & 1,972 \\
\hline $\begin{array}{c}\text { Minat } \\
\text { lulusan } \\
\text { teknisi } \\
\text { akuntansi }\end{array}$ & 7 & 35 & 26,83 & 3,857 \\
\hline Sumber : Data prim & & & \\
\hline
\end{tabular}

Sumber : Data primer diolah (2017)

Berdasarkan tabel 2 diatas dapat diketahui bahwa nilai rata - rata semua variabel dalam penelitian ini lebih besar dari standar deviasi. Hal ini berarti menunjukan bahwa nilai penyimpangan data kecil.
Uji Validitas

Hasil uji validitas untuk masing - masing pertanyaan dalam variabel yang digunakan dalam penelitian ini dapat dijelaskan dalam tabel 3 berikut ini

Tabel 3 Hasil Uji Validitas

\begin{tabular}{|c|c|c|}
\hline $\begin{array}{c}\text { Nomor } \\
\text { Pertanyaan }\end{array}$ & $\begin{array}{c}\text { Pearson } \\
\text { Correlation }\end{array}$ & Signifikan \\
\hline \multicolumn{3}{|c|}{ Pengetahuan tentang pajak } \\
\hline 1 & 0,606 & 0,000 \\
\hline 2 & 0.713 & 0,000 \\
\hline 3 & 0,750 & 0,000 \\
\hline 4 & 0,611 & 0,000 \\
\hline 5 & 0,596 & 0,000 \\
\hline \multicolumn{3}{|c|}{ Pengetahuan tentang brevet pajak } \\
\hline 1 & 0,657 & 0,000 \\
\hline 2 & 0,758 & 0,000 \\
\hline 3 & 0,746 & 0,000 \\
\hline 4 & 0,689 & 0,000 \\
\hline 5 & 0,636 & 0,000 \\
\hline \multicolumn{3}{|c|}{ Sikap terhadap profesi perpajakan } \\
\hline 1 & 0,741 & 0,000 \\
\hline 2 & 0,845 & 0,000 \\
\hline 3 & 0,774 & 0,000 \\
\hline 4 & 0,830 & 0,000 \\
\hline \multicolumn{3}{|c|}{ Norma subjektif terhadap profesi perpajakan } \\
\hline 1 & 0,662 & 0,000 \\
\hline 2 & 0,787 & 0,000 \\
\hline 3 & 0,801 & 0,000 \\
\hline 4 & 0,691 & 0,000 \\
\hline \multicolumn{3}{|c|}{ Kontrol perilaku terhadap profesi perpajakan } \\
\hline 1 & 0,685 & 0,000 \\
\hline 2 & 0,698 & 0,000 \\
\hline 3 & 0,770 & 0,000 \\
\hline 4 & 0,725 & 0,000 \\
\hline \multicolumn{3}{|c|}{ Minat lulusan teknisi akuntansi } \\
\hline 1 & 0,686 & 0,000 \\
\hline 2 & 0,749 & 0,000 \\
\hline 3 & 0,775 & 0,000 \\
\hline 4 & 0,738 & 0,000 \\
\hline 5 & 0,822 & 0,000 \\
\hline 6 & 0,755 & 0,000 \\
\hline 7 & 0,759 & 0,000 \\
\hline
\end{tabular}

Sumber : Data primer diolah (2017

Berdasarkan tabel 3 diatas maka dapat diketahui bahwa semua pertanyaan dalam variabel penelitian ini dinyatakan valid karena memiliki nilai signifikansi kurang dari 0,05. Uji Reliabilitas 
Hasil uji reliabilitas dalam penelitian ini dapat dijelaskan dalam tabel 4 berikut ini

Tabel 4 Hasil Uji Reliabilitas

\begin{tabular}{|l|c|}
\hline \multicolumn{1}{|c|}{ Variabel } & $\begin{array}{c}\text { Cronbach's } \\
\text { Alpha }\end{array}$ \\
\hline Pengetahuan pajak & 0,759 \\
\hline Pengetahuan brevet pajak & 0,775 \\
\hline Sikap tentang profesi pajak & 0,813 \\
\hline $\begin{array}{l}\text { Norma subjektif tentang } \\
\text { profesi pajak }\end{array}$ & 0,794 \\
\hline $\begin{array}{l}\text { Kontrol perilaku tentang } \\
\text { profesi pajak }\end{array}$ & 0,784 \\
\hline $\begin{array}{l}\text { Minat lulusan teknisi } \\
\text { akuntansi }\end{array}$ & 0,785 \\
\hline
\end{tabular}

Sumber : Data primer diolah (2017)

Berdasarkan tabel 4 diatas dapat diketahui bahwa semua variabel dalam penelitian ini memiliki nilai Cronbach's Alpha lebih dari 0,6 sehingga dapat dikatakan bahwa data tersebut reliabel.

\section{Uji Normalitas}

Hasil uji normalitas dalam penelitian ini dapat dijelaskan pada tabel 5 berikut ini

\section{Tabel 5. Hasil Uji Normalitas}

\begin{tabular}{|ll|r|}
\hline & & \multicolumn{1}{|c|}{$\begin{array}{c}\text { Standardized } \\
\text { Residual }\end{array}$} \\
\hline $\mathrm{N}$ & & 205 \\
Normal & Mean &, 0000000 \\
Parameters & Std. &, 98766907 \\
$\mathrm{a}, \mathrm{b}$ & Deviation &, 061 \\
Most & Absolute &, 056 \\
Extreme & Positive &,- 061 \\
Difference & Negative &, 061 \\
s & &, $061^{\mathrm{c}}$ \\
Test Statistic & \\
Asymp. Sig. (2-tailed) &
\end{tabular}

Berdasarkan hasil uji normalitas pada tabel 5 diatas menggunakan analisis statistik dengan Uji Kolmogorov Smirnov Test menunjukkan hasil 0,061>0,05 sehingga dikatakan data berdistribusi normal.
Uji Multikolinearitas

Hasil uji multikolinearitas dalam penelitian ini dapat dijelaskan pada tabel 6 berikut ini

Tabel 6 Hasil Uji Multikolinearitas Coefficients $^{\mathrm{a}}$

\begin{tabular}{|c|c|c|}
\hline \multirow[b]{2}{*}{ Model } & \multicolumn{2}{|c|}{$\begin{array}{c}\text { Collinearity } \\
\text { Statistics } \\
\end{array}$} \\
\hline & Tolerance & VIF \\
\hline 1 (Constant) & & \\
\hline Pengetahuan pajak & ,718 & 1,392 \\
\hline $\begin{array}{l}\text { Pengetahuan brevet } \\
\text { pajak }\end{array}$ & ,639 & 1,566 \\
\hline $\begin{array}{l}\text { Sikap tentang profesi } \\
\text { pajak }\end{array}$ &, 710 & 1,409 \\
\hline $\begin{array}{l}\text { Norma subjektif } \\
\text { profesi pajak }\end{array}$ &, 566 & 1,767 \\
\hline $\begin{array}{l}\text { Kontrol perilaku } \\
\text { profesi pajak }\end{array}$ &, 570 & 1,755 \\
\hline
\end{tabular}

Sumber : Data primer diolah (2017)

Berdasarkan hasil uji multikolinearitas pada tabel 6 diatas dapat diketahui bahwa variabel independen dalam penelitian ini memiliki nilai tolerance $>0,10$ dan nilai VIF < 10 sehingga dapat dinyatakan bahwa tidak terjadi masalah multikolinearitas antara variabel independen dalam model regresi.

Uji Heterokedastisitas

Hasil uji heterokedastisitas dalam penelitian ini dapat dijelaskan pada tabel 7 berikut ini

\begin{tabular}{|l|r|}
\hline & \\
Model & \multicolumn{1}{|c|}{ Sig. } \\
\hline 1 (Constant) &, 000 \\
Pengetahuan pajak &, 216 \\
Pengetahuan brevet pajak &, 567 \\
Sikap &, 081 \\
Norma subjektif &, 240 \\
kontrol perilaku &, 062 \\
\hline
\end{tabular}

Tabel 7 Hasil Uji Heterokedastisitas

Sumber : Data primer diolah (2017) 


\begin{abstract}
Berdasarkan hasil uji heterokedastisitas dengan uji glejser menunjukan nilai Sig. variabel independen dalam penelitian ini lebih besar dari nilai alpha 0,05 yang berarti model regresi tidak terjadi gejala heterokedastisitas.
\end{abstract}

Uji Autokorelasi

Hasil uji autokorelasi dalam penelitian ini dapat dijelaskan pada tabel 8 berikut ini

Tabel 8 Hasil Uji Autokorelasi

\title{
Runs Test
}

\begin{tabular}{|l|r|}
\hline & \multicolumn{1}{|c|}{$\begin{array}{c}\text { Unstandardized } \\
\text { Residual }\end{array}$} \\
\hline Test Value $^{\mathrm{a}}$ &,- 27665 \\
Cases < Test Value & 102 \\
Cases >= Test Value & 103 \\
Total Cases & 205 \\
Number of Runs & 103 \\
Z &,- 070 \\
Asymp. Sig. (2-tailed) &, 944 \\
\hline
\end{tabular}

Sumber : Data primer diolah (2017)

Tabel 9. Hasil Uji Statistik t

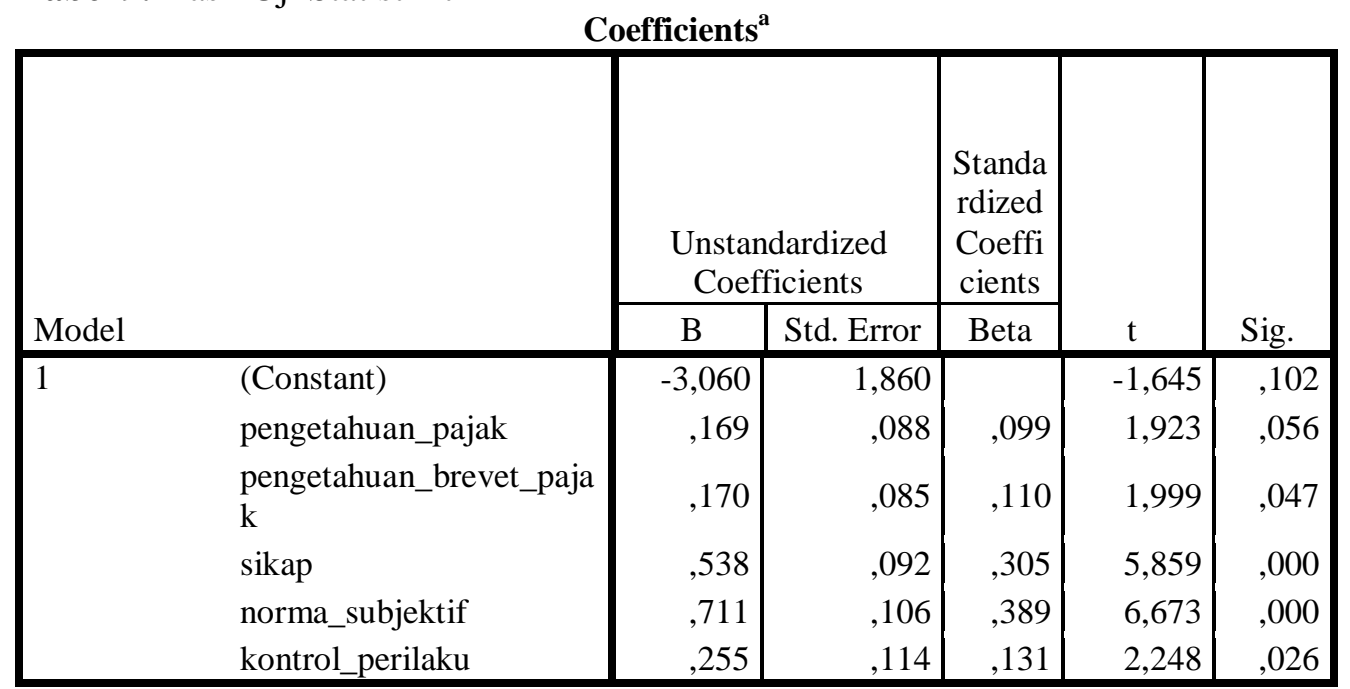

Sumber : Data primer diolah (2017)

Berdasarkan hasil uji t (parsial) pada tabel diatas menunjukkan bahwa variabel pengetahuan brevet pajak, sikap, norma subjektif dan kontrol perilaku memiliki nilai signifikansi lebih kecil dari taraf signifikansi 0,05 (5\%). Hal ini menunjukkan bahwa variabel pengetahuan brevet pajak, sikap tentang profesi pajak, norma subjektif tentang profesi pajak dan kontrol perilaku tentang profesi pajak berpengaruh signifikan terhadap minat bekerja di bidang perpajakan. Sedangkan variabel pengetahuan pajak memiliki nilai signifikansi sebesar 0,056 yang lebih besar dari taraf signifikansi 0,05 sehingga pengetahuan pajak tidak berpengaruh signifikan terhadap minat bekerja di bidang perpajakan 


\section{Uji Statistik F}

Hasil uji statistik $\mathrm{F}$ dalam penelitian ini dapat dijelaskan pada tabel 10 berikut ini Tabel 10 Hasil Uji Statistik F

\begin{tabular}{|l|r|r|r|r|l|}
\hline & $\begin{array}{c}\text { Sum } \\
\text { of } \\
\text { Square } \\
\text { Model }\end{array}$ & $\begin{array}{r}\text { MNOVA } \\
\text { df }\end{array}$ & $\begin{array}{c}\text { Mean } \\
\text { Squar } \\
\text { e }\end{array}$ & F & Sig. \\
\hline Regres & 1875,0 & 5 & 375,0 & 64,3 &, $000^{\mathrm{b}}$ \\
sion & 02 & & 00 & 31 & \\
Residu & 1160,0 & 199 & 5,829 & & \\
al & 23 & & & & \\
Total & 3035,0 & 204 & & & \\
\hline
\end{tabular}

Sumber : Data primer diolah (2017)

Berdasarkan hasil uji $\mathrm{F}$ (simultan) pada tabel diatas menunjukkan hasil bahwa variabel pengetahuan pajak, pengetahuan brevet pajak, sikap, norma subjektif dan kontrol perilaku memiliki nilai signifikansi lebih kecil dari taraf signifikansi 0,05 (5\%). Hal ini menunjukkan bahwa variabel pengetahuan pajak, pengetahuan brevet pajak, sikap tentang profesi pajak, norma subjektif tentang profesi pajak, kontrol perilaku tentang profesi pajak berpengaruh secara simultan dan signifikan terhadap minat bekerja dibidang perpajakan

Pembahasan

Hasil pengujian hipotesis variabel pengetahuan tentang pajak menunjukkan nilai signifikansi sebesar 0,056 yang berarti lebih besar dari taraf signifikansi 0,05 sehingga dapat diketahui bahwa Ha ditolak. Hal ini berarti bahwa pengetahuan tentang pajak secara parsial tidak berpengaruh signifikan terhadap minat lulusan teknisi akuntansi untuk bekerja dibidang perpajakan. Hal ini menunjukkan bahwa lulusan teknisi akuntansi menyatakan pengetahuan tentang pajak yang dimiliki tidak mendukung minat lulusan untuk bekerja dibidang perpajakan. Pengetahuan pajak yang dimiliki oleh lulusan tidak serta merta hanya bisa digunakan untuk bekerja dibidang perpajakan tetapi bisa dijadikan bekal untuk bekerja pada sektor pekerjaan apapun. Selain itu, lulusan teknisi akuntansi menganggap bahwa pengetahuan pajak yang dimiliki masih sangat kurang sehingga belum memiliki kemampuan yang baik untuk bekerja dibidang perpajakan. Hal ini karena bekerja dibidang perpajakan harus didukung dengan pengetahuan tentang pajak yang baik dan kompeten agar tidak salah dalam melaksanakan pekerjaan nantinya. Hasil penelitian ini sejalan dengan penelitian yang dilakukan oleh Yulianti, Arisman dan Wenny $(2016)^{[2]}$ yang menyatakan bahwa kemampuan tidak berpengaruh secara parsial terhadap minat mahasiswa berkarir di bidang perpajakan.

Hasil pengujian hipotesis variabel pengetahuan tentang brevet pajak menunjukkan nilai signifikansi sebesar 0,047 yang berarti lebih kecil dari taraf signifikansi 0,05 sehingga dapat diketahui bahwa $\mathrm{Ha}$ diterima. Hal ini berarti bahwa pengetahuan tentang brevet pajak secara parsial berpengaruh signifikan terhadap minat lulusan teknisi akuntansi untuk bekerja dibidang perpajakan. Hal ini menunjukkan bahwa lulusan teknisi akuntansi menganggap pengetahuan tentang brevet pajak mendukung minat lulusan teknisi akuntansi untuk bekerja dibidang perpajakan. Hal ini karena brevet pajak merupakan pendidikan dan pelatihan tentang pajak yang tersertifikasi sehingga dapat menjadi bukti bahwa telah kompeten dibidang pajak. Hal tersebut dapat membuat lulusan teknisi akuntansi lebih percaya diri dalam menghadapi pekerjaan dibidang pajak nantinya karena telah memiliki sertifikat kompetensi bidang pajak. Oleh karena itu ketika lulusan teknisi akuntansi telah memiliki sertifikat brevet pajak A, B dan C maka dapat mendorong minat untuk bekerja dibidang perpajakan. Hasil penelitian ini sejalan dengan penelitian yang dilakukan oleh Sutrawati, Sirojuddin dan Fajriana $(2016)^{[3]}$, yang menyatakan bahwa pengetahuan tentang brevet pajak berpengaruh secara parsial terhadap minat berprofesi dibidang perpajakan. 
Hasil pengujian hipotesis variabel sikap tentang profesi pajak menunjukkan nilai signifikansi sebesar 0,000 yang berarti lebih kecil dari taraf signifikansi 0,05 sehingga dapat diketahui bahwa Ha diterima. Hal ini berarti bahwa sikap tentang profesi pajak secara parsial berpengaruh signifikan terhadap minat lulusan teknisi akuntansi untuk bekerja dibidang perpajakan. Hal ini menunjukkan bahwa lulusan teknisi akuntansi memandang sikap tentang profesi pajak dalam hal positif yang mendukung minat untuk bekerja dibidang perpajakan. Sikap yang positif terkait profesi dibidang pajak dapat dilihat dari penilaian lulusan yang menyatakan bahwa pekerjaan dibidang perpajakan merupakan pekerjaan yang bergengsi dengan penghasilan yang tinggi dan karir yang jelas serta merupakan kebanggaan tersendiri ketika dapat bekerja dibidang perpajakan karena tidak semua lulusan dapat memperoleh pekerjaan tersebut. Hasil penelitian ini sejalan dengan penelitian yang dilakukan oleh Hartbian (2014) ${ }^{[4]}$ yang menyatakan bahwa sikap perilaku tentang profesi perpajakan mempengaruhi secara signifikan dalam memilih berprofesi dibidang perpajakan. Hasil pengujian hipotesis variabel norma subjektif tentang profesi perpajakan menunjukkan nilai signifikansi sebesar 0,000 yang berarti lebih kecil dari taraf signifikansi 0,05 sehingga dapat diketahui bahwa Ha diterima. Hal ini berarti bahwa norma subjektif tentang profesi perpajakan secara parsial berpengaruh signifikan terhadap minat lulusan teknisi akuntansi untuk bekerja dibidang perpajakan. Hal ini menunjukkan bahwa norma subjektif tentang profesi pajak dapat memberikan dukungan untuk bekerja dibidang perpajakan. Norma subjektif dapat ditunjukkan dengan dukungan para dosen yang memberikan motivasi kepada lulusan untuk bekerja di bidang perpajakan. Selain itu, norma subjektif juga didukung dengan adanya rekan-rekan lulusan yang banyak tertarik untuk bekerja dibidang perpajakan. Oleh karena itu, dengan dukungan dari dosen dan teman-teman yang positif maka menarik minat lulusan teknisi akuntansi untuk bekerja dibidang pekerjaan. Hasil penelitian ini tidak sejalan dengan penelitian yang dilakukan oleh Hartbian (2014) $)^{[4]}$ yang menyatakan bahwa norma subjektif tentang profesi perpajakan tidak mempengaruhi secara signifikan dalam memilih berprofesi dibidang perpajakan.

Hasil pengujian hipotesis variabel kontrol perilaku tentang profesi perpajakan menunjukkan nilai signifikansi sebesar 0,026 yang berarti lebih kecil dari taraf signifikansi 0,05 sehingga dapat diketahui bahwa $\mathrm{Ha}$ diterima. Hal ini berarti bahwa kontrol perilaku tentang profesi perpajakan secara parsial berpengaruh signifikan terhadap minat lulusan teknisi akuntansi untuk bekerja dibidang perpajakan. Hal ini menunjukkan bahwa kontrol perilaku tentang profesi pajak dapat memberikan dukungan yang positif untuk bekerja dibidang perpajakan. Kontrol perilaku dapat ditunjukkan dengan banyaknya lowongan pekerjaan dibidang perpajakan yang dapat menarik minat lulusan untuk bekerja di bidang pajak. Selain itu, kontrol perilaku juga didukung dengan indeks prestasi yang dimiliki oleh lulusan sehingga akan mempengaruhi minat lulusan untuk bekerja dibidang perpajakan karena indeks prestasi yang baik maka akan memberikan peluang yang terbuka untuk bekerja dibidang perpajakan. Hasil penelitian ini tidak sejalan dengan penelitian yang dilakukan oleh Hartbian (2014) $)^{[4]}$ yang menyatakan bahwa kontrol perilaku tentang profesi perpajakan tidak mempengaruhi secara signifikan dalam memilih berprofesi dibidang perpajakan

\section{Kesimpulan Dan Saran}

Berdasarkan hasil penelitian dan pembahasan maka dapat diambil kesimpulan sebagai berikut :

a. Variabel pengetahuan tentang pajak tidak berpengaruh signifikan terhadap minat lulusan teknisi akuntansi untuk bekerja dibidang perpajakan.

b. Variabel pengetahuan tentang brevet pajak berpengaruh signifikan terhadap 
minat lulusan teknisi akuntansi untuk bekerja dibidang perpajakan.

c. Variabel sikap tentang profesi pajak berpengaruh signifikan terhadap minat lulusan teknisi akuntansi untuk bekerja dibidang perpajakan.

d. Variabel norma subjektif tentang profesi pajak berpengaruh signifikan terhadap minat lulusan teknisi akuntansi untuk bekerja dibidang perpajakan.

e. Variabel kontrol perilaku tentang profesi pajak berpengaruh signifikan terhadap minat lulusan teknisi akuntansi untuk bekerja dibidang perpajakan.

\section{Daftar Pustaka}

[1] Dayshandi, Handayani, Yaningwati. 2015. Pengaruh Persepsi Dan Motivasi Terhadap Minat Mahasiswa Program Studi Perpajakan Untuk Berkarir Di Bidang Perpajakan (Studi pada mahasiswa Fakultas Ilmu Administrasi Universitas Brawijaya). Jurnal Perpajakan (JEJAK) Volume 1 No. 1 Januari 2015. Universitas Brawijaya Malang

[2] Yulianti, Arisman, Wenny. 2016. Pengaruh Motivasi, Self Efficacy, dan Kemampuan Terhadap Minat Mahasiswa Berkarir Dibidang Perpajakan (Studi Kasus Mahasiswa di Kota Palembang). Jurusan Akuntansi STIE MDP Palembang

[3] Sutrawati, Sirojuddin, Fajriana. 2016. Pengaruh Pengetahuan Mahasiswa Akuntansi Di Palembang Tentang Pajak dan Brevet Pajak Terhadap Minat Berprofesi Dibidang Perpajakan. Jurusan Akuntansi STIE Multi Data Palembang

[4] Hartbian, Yafet Wijaya. 2014. FaktorFaktor Yang Mempengaruhi Minat Mahasiswa Akuntansi Universitas Kristen Satya Wacana Untuk Bekerja Dibidang Perpajakan. Skripsi. Jurusan
Akuntansi Universitas Kristen Satya Wacana Salatiga

[5] www.sdm.kemenkeu.go.id

[6] www.konsultan.pajak.go.id 